\title{
Written and Unwritten Building Conventions in a Contested City: The Case of Belfast
}

\author{
Ralf Brand
}

[Paper first received, August 2008; in final form, June 2009]

\begin{abstract}
Many design conventions are legally binding, state-issued building codes and regulations, but many others derive their authority from other sources, are enforced by other means and exist for other purposes. This paper therefore introduces a scheme to cover the wide variety of de facto building conventions. Particularly interesting examples of seemingly atypical conventions can be found in Northern Ireland where the specific socio-political situation requires particular design approaches. Many design conventions guide the creation of artefacts that attempt to influence people's behaviour. The distinction between corpo-active versus symbolic mechanisms and socio-fugal versus socio-petal effects is introduced in order to grasp further differences between such socio-active artefacts. The latter are of special significance in situations where communities in strife are slowly learning to practise a peaceful co-existence, as is demonstrated with one specific case study.
\end{abstract}

\section{Introduction}

Ideas about the ideal shape of our built environment are often cast into elaborate, legally binding, government-issued building codes-but also into a vast array of other regulations, rules, standards, codes and conventions. The first part of this paper illustrates this variety with a wide range of conventions that effectually influence the design of our material surroundings despite some of them being not much more than rules-of-thumb. As a heuristic tool to think systematically about this diversity, I suggest differentiating certain key parameters of such conventions. Although this might be a worthwhile intellectual contribution in its own right, my main purpose is to sharpen the focus of the rest of this paper which deals specifically with conventions that govern the design of artefacts with a built-in agenda of influencing behaviour.

Ralf Brand is in the School of Environment and Development/MARC Humanities Bridgeford St, The University of Manchester, Oxford Road, Manchester, M13 9PL, UK.

E-mail: ralf.brand@manchester.ac.uk. 
The architectural and urban design praxis in the 'contested' city of Belfast serves as the empirical background of this analysis because it provides high-contrast examples of precisely such design conventions. Some typical features of Northern Ireland's built environment result from attempts either to discourage people from undesired behaviours or to encourage them to desired ones. The former have been widely applied and investigated in this and other contexts under the rubric of environmental criminology. The latter, and the focus of the final part of this paper, are becoming more acknowledged as a possible contribution by architects and planners to the reconciliation efforts in Belfast and in cities with similar challenges. This potential is exemplified with an investigation of the design features of a new building which provides everyday facilities for Catholics and Protestants, two communities with a history of violence towards each other.

\section{Parameters of Design Conventions}

The shape of a building, a street or a public space is a function of many factors. The vision and financial prowess of the client, assumptions of users' behavioural patterns, the architect's abilities and aesthetic preferences, the engineer's calculations and the chosen material's structural qualities certainly have an effect, but so also do the applicable building codes, regulations and conventions. That conventions govern the shape of a building is nothing new. In fact, Hammurabi's Code of Law (1792-50 BC) already contained rules about the construction of buildings. In the early 21 st century Ben-Joseph (2005, xiii) argues that now "standards and codes ... virtually dictate all aspects of urban development".

While I do not agree that building codes "dictate" the shape and direction of urban development, they certainly limit the autonomy (or whim) of designers. It would therefore be foolish to ignore them. Put positively, if we want to understand where building conventions really originate, how they influence the way designers really work and how they co-shape our cities and lives, we should devote serious effort to their study. A useful startingpoint for such a project is a systematic differentiation between the various parameters of building conventions: their authorship and origin; their degrees of power and their enforcement mechanisms; their forms of expression, rationales and purposes, that is, their intended outcomes. The rows in Figure 1 represent these parameters and are introduced in the following.

With regard to the authorship of design conventions (the first row), it is im-portant to widen the view from governmental or municipal entities, the most apparent sources of building codes, to the whole range of related non-governmental bodies. For example, the British Building Research Establishment (BRE) exerts enormous influence on the shape of the built environment through its BREEAM certification (Building Research Establishment Environmental Assessment Method). Numerous comparable industry standards influence the design of buildings in similar ways. Even insurance companies can, by implication, influence the shape of a building through the mathematics behind the calculation of building insurance premiums. Neither are developers, charities or professional associations necessarily passive receivers of regulations; many lobby constantly for favourable definitions of laws, building regulations and certification algorithms.

The power and enforcement mechanisms of building conventions (rows 2 and 3 ) typically directly correlate with their sources. Statutory building regulations are usually endowed with the force of law and can be upheld in courts. The power of other conventions is often based on the desirability of certificates and plaques as marketing tools 


\begin{tabular}{|c|c|c|c|c|c|c|c|c|}
\hline 1 & Authorship & \multicolumn{2}{|l|}{ State } & \multicolumn{2}{|l|}{ Industry } & \multicolumn{3}{|l|}{ Other } \\
\hline 2 & Power & \multicolumn{2}{|c|}{ Legal force } & \multicolumn{2}{|c|}{ Certification } & \multicolumn{3}{|c|}{ Expectations } \\
\hline 3 & Enforcement & \multicolumn{2}{|l|}{ Courts } & Withdrawal & \multicolumn{2}{|c|}{ Civil disobedience } & \multicolumn{2}{|c|}{ Failure } \\
\hline 4 & Expression & \multicolumn{3}{|c|}{ Explicit/written } & \multicolumn{4}{|c|}{ Implicit/tacit } \\
\hline 5 & Rationale & Legality & $\begin{array}{l}\text { Best } \\
\text { practice }\end{array}$ & $\begin{array}{l}\text { Common } \\
\text { sense }\end{array}$ & $\begin{array}{l}\text { Tradition/ } \\
\text { vernacular }\end{array}$ & \multicolumn{2}{|c|}{ Practicality } & $\begin{array}{l}\text { Vested } \\
\text { interests }\end{array}$ \\
\hline 6 & Socio-activity & \multicolumn{3}{|c|}{ Socio-active } & \multicolumn{4}{|c|}{ Socio-inactive } \\
\hline
\end{tabular}

Figure 1. Parameters of design conventions

or simply on strong collective expectations. Although not legally binding, they can be enforced through the threatening of a lower rank on a certification ladder, the looming danger of damage to reputation, or the matterof-fact failure of a design in terms of financial losses, structural damage, high-maintenance, user discomfort or even sabotage.

While most of these conventions are typically expressed in some written form, others are not (row 4). Religious traditions, for example, can effectively prescribe certain design features for places of worship, such as the orientation of churches and mosques. Such unwritten, implicit or tacit conventions can originate from an almost unlimited range of sources, including folk lore, vernacular experience and codes of decency amongst others. In some cases, ideas about the ideal shape of our material surrounding are not much beyond the cognitive sophistication of rulesof-thumb and are therefore not even recognised or acknowledged as conventions. In such cases, they may simply have become internalised, have turned into second nature, into common sense.

The rationale and purpose of different types of convention vary as well (row 5).
Ben-Joseph (2005, p. x) argues, for example, that the historical origin of building conventions has to do with the desire to "bring order and safety to the city building process". I tend to agree that many design regulations owe their existence to such perfectly benevolent intentions. These may include the desire to disseminate experience from pilot schemes, to codify what some people genuinely consider true, beautiful and good, to ensure the implementation and reproduction of traditional knowledge, as well as other collective environmental, economic and social agendas. ${ }^{1}$ However, this does not cover the total range of reasons for the existence of building conventions. They are also intended to create or assert shared bodies of knowledge and common understanding between different actors (Imrie and Street, this issue, p. 2511), and they typically embody struggles over power and influence. Those who manage to define and popularise conventions get a voice at the decision-making table even when absent (Callon, 1986). Established regulations also make it easier for their adherents to win arguments and to "close the Black box" (Latour, 1999) of the messy decision-making process. In addition, those who are in charge of 
design can hide their responsibility behind the argumentative shield of conventions and thus depoliticise certain debates.

\section{Close-up of Socio-active Design Conventions}

The final sub-heading in Table 1 represents a further differentiation of design conventions, between those that guide the design of artefacts with 'socio-active' content and those that do not. I suggest this adjective (Brand, 2008) to denote artefacts with certain qualities that exert some kind of gravitational pull on their users' behaviour. Such artefacts, in other words, have a degree of agency which derives from their 'affordances' (Gibson, 1977), as environmental psychologists might say, or from their 'scripts' (Akrich, 1992), 'programmes' (Latour, 1992) or 'agendas' (Brand, 2008) per some scholars in the field of science and technology studies. For reasons mentioned later, I consider socio-active artefacts of particular importance in a contested city such as Belfast.

Before the argument proceeds to a conceptual differentiation between two subdimensions of socio-active design features, it seems useful to address potential criticism of the very notion of socio-activity. For some, the idea that artefacts impact upon our behaviour is an anathema because of its eerie proximity to environmental determinism and social engineering. My interest in socioactive artefacts-and the conventions that guide their design — does not at all imply an endorsement of such behaviouristic stimulusresponse models, but to refuse to think about non-human agency is illogical. To me, there is no doubt that our physical environmentamong many other factors-intercedes in our everyday social practices. Built environment professionals even employ this logic on a daily basis when they build speed bumps, anti-skateboarding knobs, bollards, bicycle lanes and a plethora of other artefacts. This does not equate to a material-fix ideology or to a belief in the capability of good design to solve all social ills, but it is an acknowledgement that together many factors $c o$-determine our behaviour and that one of these factors is our built environment. In other words, artefacts do have some kind of agency, although it is merely a single agency in a messy vector-field teeming with different agencies: human and non-human alike. Very few architectural scholars have addressed this issue in any reasonable depth. The fact that the description and analysis of socio-active artefacts occupies considerable space in the remaining text is exactly because of this lack in the existing literature. It does not indicate a belief that socio-active artefacts are somehow more important than other agents, but that they are unique, rather typical and frequently occur in contested cities where morality is often outsourced to artefacts with hidden or even overt agendas.

As mentioned earlier, the following two paragraphs introduce two sub-dimensions of socio-active design features: corpo-active versus symbolic; and behaviour-petal versus behaviour-fugal. These two categories are plotted in a matrix (Table 1) whose cells are further filled with empirical content further in the discussion that follows.

\section{Corpo-active versus Symbolic Mediation}

Some socio-active urban design features 'speak to the body', ${ }^{2}$ and others do not. The former have a direct or immediate effect on our social practices as em-bodied beings. A fence, for example, prevents us from stepping onto the territory beyond it in a physical and very direct way. A sign of a barking dog

Table 1. Typology of socio-active design features

\begin{tabular}{l|l|l}
\hline & Socio-fugal & Socio-petal \\
\hline Corpo-active & & \\
\hline Symbolic & & \\
\hline
\end{tabular}


might have the same effect but only because of its semiotic quality-its effect is mediated through our cognitive or internalised knowledge of the symbol's meaning. Another way of saying this is: We could walk past the dog symbol without any extra physical effort, but not past the fence. The distinction between artefacts that do and those that do not directly impact on our body is not new. Oscar Newman, one of the founding fathers of CPTED (Crime Prevention Through Environmental Design), describes the idea of defensible space in these terms by distinguishing between "real and symbolic barriers" (Newman, 1972b, p. 3). Other scholars are thinking along similar lines but using different words. Verbeek (2005), for example, distinguishes between micro- and macro-perception to denote what I call corpo-active versus symbolic. What matters is not the choice of words, but the fact that we have some suitable semantic tools at our disposal to investigate and communicate these characteristics.

\section{Behaviour-petal versus Behaviour-fugal Effects}

The distinction between socio-petal and sociofugal was coined by Humphrey Osmond (1957) to capture the effects of different seating arrangements and room layouts in a psychiatric ward. A socio-petal space is "a physical environment designed to encourage interpersonal interaction" (Corsini, 1999, p. 921) whereas a socio-fugal setting is "a place where people typically try to avoid one another" (Sommer, 1967, p. 657). This thinking acknowledges (or assumes) that certain physical settings can either prevent, discourage, hamper, slow conviviality or they can 'allow, permit, enable, authorise' it, to paraphrase Latour (2004). The latter effect is precisely what Henry Shaftoe tries to translate to the urban level in his collection of design standards for the creation of "Convivial Spaces" (2008). It is not a far cry to extend this logic to the idea that certain spatial and material arrangements may accommodate certain behaviours in general to a greater or lesser degree. I therefore suggest the term behaviourpetal to describe artefacts that make certain desired social practices convenient, pleasant and-of particular importance in Northern Ireland-safe. Conversely, the intended effect of behaviour-fugal artefacts is to discourage certain behaviours.

\section{Belfast as Empirical Context}

Ideally, an investigation into the role and explanatory power of building regulations, rules, standards, codes and conventions would control all potential alternative explanatory variables. Due to their number, such an approach is not feasible, definitively, as there could be no quantitative test of statistical significance. What can be given, however, is a description and analysis of one case in depth to see whether its story contains a significantly different constellation of factors from what we know to exist in settings elsewhere. In this paper, I therefore describe and analyse related issues in a unique, because highly contested, urban setting within the UK. The term 'contested city' has been suggested to denote places whose diversity is not embraced as an asset but as a source of competing territorial claims, segregation, intimidation and even violence. Jerusalem, Beirut, Mostar and many others qualify for this arguable label (Bollens, 2002; Charlesworth, 2006; Purbrick et al., 2007) and so does Belfast, the capital of Northern Ireland, which has suffered many decades of acrimonious troubles between its Loyalist and Republican citizens, with the British state, its police force and its army caught in between and disliked by both parties.

The quarrels in Northern Ireland have deep historical roots which cannot be the focus of this paper. What is indispensable as background understanding is the 'constitutional 
question', that is, the unresolved dispute over the national belonging of the north-eastern part of the island of Ireland. Many Catholics, Nationalists and Republicans argue that it should be part of the Republic of Ireland. Equally, many Protestants, Unionists and Loyalists claim that it is a legitimate part of the United Kingdom. These two ethnic, religious, linguistic groups have never been evenly spread across the territory of Belfast. This spatial clustering became more pronounced during the city's industrial heyday when the accelerated need for manual labour drew many Catholic families from rural parts of the island to the boom-town in the northeast where they tended to settle either in proximity to the existing Irish community or where space was available, which was largely in the west of the city. While some physical barriers separating the two communities were built in the early 20th century, they were never a prominent feature of Belfast's urban fabric until 1969 when a phase of extremely violent atrocities, known as 'The Troubles', began. Bombing campaigns, street battles and arson attacks against "25 000 households" (Calame and Charlesworth, 2008, p. 80) triggered the exodus of thousands of families from relatively mixed areas into the heartland of 'their' community which resulted not only in collective trauma, deep-seated hatred and a seemingly hereditary mistrust, but also in a staggering degree of segregation. In 2005, the percentage of Belfast's population living in severely segregated wards (whose population is 90 per cent or more homogeneous by religion) was 55.4 per cent (Morrissey and Gaffikin, 2006, p. 881).

Many urban artefacts in Belfast owe their existence, shape and sometimes even colour to this socio-political condition (Brand, 2009). Most notorious are probably the 88 'security and segregation barriers' (Community Relations Council, 2008), many known as 'peace walls', separating Catholic from Protestant communities. These barriers are made of concrete, brick or corrugated metal, often with barbed wire on top, and extend up to $1.6 \mathrm{~km}$ in length and 12 metres in height. However, the manifestation of conflict is not only visible in monumental walls, but also in the design of houses, neighbourhoods and streets. The footpaths in the Poleglass development, for example, were allegedly constructed to full road specification to facilitate access for heavy army vehicles (Alcorn, in Murtagh 2002). Similar observations (or rumours) have been circulating in the planning community for many years (for example, Cowan, 1982; Hillyard, 1983; Dawson, 1984). The origin and impact of Belfast's unique spatial layout, related planning practice and urban policy have been the focus of scholarly investigations for several decades with seminal contributions by Boal (1998, 1999), Bollens (1999, 2002), McEldowney et al. (2001), Murtagh (2002), Shirlow and Murtagh (2006), Shuttleworth and Lloyd (2006), Gaffikin and Morrissey (2006), Calame and Charlesworth (2008) and others. Little attention has, however, been drawn to the explicit or tacit rationales that motivate the shapers of Belfast's urban environment. These include, of course, official planners and architects but also community groups, designers of playgrounds, engineers of peace walls and ALOs (architectural liaison officers) of the police forces amongst others.

As the following examples show, contested cities seem particularly suitable cases from which to develop a holistic understanding of design conventions because they provide high-contrast scenarios where the variety of authors, power and enforcement mechanisms, rationales, forms of expression and degrees of socio-activity are clearly visible. The latter are especially of primary interest because of their particular prevalence and importance in a city like Belfast. If disregarded, the resulting design can literally be lethal. 
A classic unwritten convention in Northern Ireland, for example, dictates that bushes are not to be planted near violent interfaces between Nationalist and Loyalist areas because they could provide cover for potential perpetrators. Trees are a similarly problematic feature because they allow aggressors to climb them in order to throw various projectiles even further into enemy territory. These and many other design principles employed in Northern Ireland are meant to prevent or discourage undesired behaviour. However, others - which are of increasing importance during the so-called peace processaim to encourage desired behaviour. This differentiation guides the analysis of empirical findings in the remainder of this paper.

\section{Creating Shared Spaces}

The majority of CPTED principles fall into the socio-fugal category which is enormously problematic in the case of Northern Ireland because the definitions of undesired behaviour vary hugely between the various players. For example, what the British state declares as terrorism is a legitimate 'armed struggle' for independence by Irish Nationalists. The range of stakeholders also includes Loyalist and Republican paramilitary groups, ordinary Catholic and Protestant citizens, retailers, political parties, the police service, the state and so on. All of them have different ideas of what types of behaviour should be discouraged, which, in theory, renders the generation of design conventions-written, unwritten, statutory or commonsensicalmassively controversial. In practice, however, the results are of limited complexity because, unlike in other contested cities, it is difficult for sectarian interests to trump the bureaucratic neutrality of the planners' and developers' desire to protect themselves from reputational damage and their investments from physical damage. Given these prevailing power structures, sectarian attacks are therefore defined as a form of crime de facto, which explains the wide application of socio-fugal CPTED principles in Northern Ireland.

The focus of this paper, however, is not only on the arsenal designers employ to quell conflict through socio-active interventions, but also on architectural attempts to propel positive change. This ambition is equally controversial because not everybody agrees that a peaceful relationship between the two main communities is the best way to achieve a vision of peace. However, we know from the referendum result for the Belfast Agreement (Good Friday Agreement, 1998) that 71 per cent of Northern Ireland's population indicated that they would prefer an amicable future. Even the political parties that represent both groups in Stormont, Northern Ireland's parliament, agree on this point. This implies wide consensus about the definition of desirable behaviour and makes it methodically manageable to investigate the praxis and potential of architects to contribute to the peace process through behaviour-petal spaces where it is safe and convenient to make friendly encounters with 'others'. It is important to understand the explicit and tacit logics behind such attempts because this knowledge could assist the spread and replication of such neutral or even shared spaces.

Unfortunately, not many examples of successful shared spaces exist-yet. This is not simply due to a lack of trials. The Farset Community Farm, for example, or the Clovelly Street Redevelopment Area, both in Belfast, started with the ambition to provide space where people from both sides of the ethnic/ religious divide could mingle. However, they fell victim to violent attacks in the former case and to deeply ingrained segregation habits in the latter.

The Stewartstown Road Regeneration Project (SRRP; www.stewartstownroad.org) 
in Outer West Belfast is a notable exception. It is located at the interface between the predominantly Protestant enclave of Suffolk and the predominantly Catholic area Lenadoon (Figure 1). The Stewartstown Road was the site of countless violent clashes between these two groups, the police and the British Army over several decades and was therefore fortified with a so-called peace wall, intended to keep the warring factions apart. Over the past 10 years, however, some courageous individuals from both sides took the initiative to develop a more peaceful relationship between their communities which resultedafter many years of negotiations, disputes, highs and lows (Hall, 2007) —in the construction of a jointly owned and managed, twostorey building. Its roughly 1000 square metres accommodate offices for community groups from within both communities, four retail units and commercially let office space. The scheme is widely considered a financial and social success with a long waiting-list for the retail units, general acceptance among most residents of the adjoining communities, absence of sectarian graffiti and income generation for community initiatives. This experience energised the construction of a second phase, which extended the building by two more retail units, more office space and a separate nursery (Figure 2).

As one of very few successful shared spaces in Northern Ireland, SRRP deserves closer scrutiny which must include attention to the process and content of its material design. Some, if not most, of its design features fall under the rubric of designing-out crime, as it is still necessary to prevent bad things from happening before good things have a chance to grow. However, questions as to how the

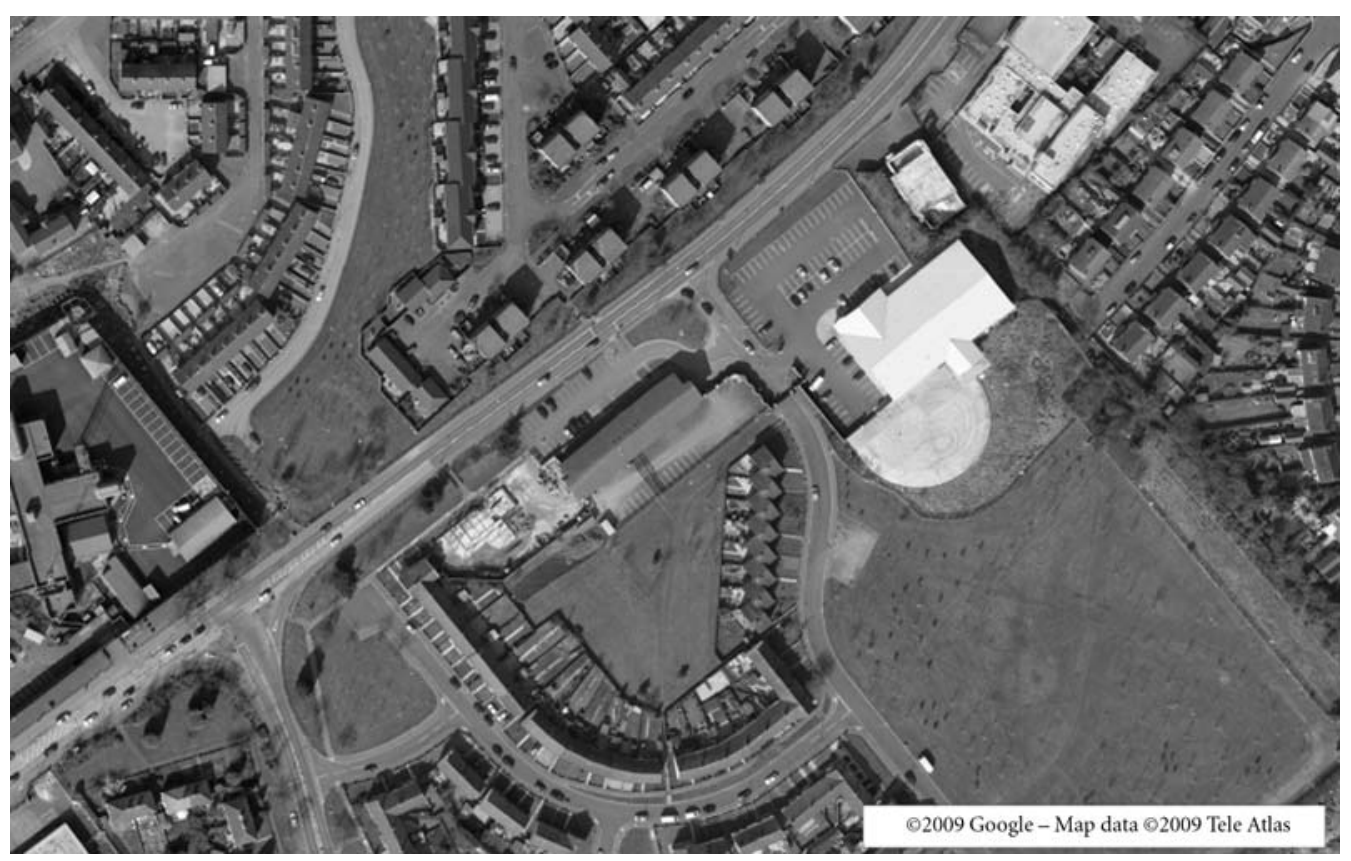

Figure 2. Stewartstown Road runs from south-west to north-east. SRRP (phase II under construction) is in the centre of the image. The predominantly Unionist neighbourhood Suffolk lies to its south-east. The northern and eastern areas on the image are part of Lenadoon which is predominantly Nationalist. The complex in the centre left is part of a heavily fortified police station. The white roof to the right of SRRP belongs to a supermarket 
latter can be facilitated through appropriate architectural solutions were nonetheless very important during the design process and attempts are now under way to extract lessons from this case as to how best-practice in the sense of design conventions for the creation of successful shared spaces can occur. There is no dearth of potential recipients for such knowledge as various other community groups throughout Northern Ireland are eager to replicate SRRP's success. The Northern Ireland Housing Executive (NIHE) also endorses the idea of shared space and intends to increase the religious mix of its housing estates. Together with the Housing Association Ulidia, NIHE developed the cross-community estate Carran Crescent in Enniskillen, County Fermanagh, which is now home to Catholics and Protestants, as well as recent eastern European immigrants. It is the first planned cross-community housing estate in Northern Ireland, but plans for more and larger shared housing projects are currently under way.

I collected a significant part of the following empirical material during a 15-month residence at Queen's University Belfast in 2005 and 2006. Since then, I have conducted two further phases of field work in Belfast of three days (2007) and two weeks (2008), focusing specifically on SRRP. ${ }^{3}$ In total, I conducted 37 semi-structured interviews with architects, planners, academics from various disciplines, representatives of various state agencies and numerous decision-makers and stakeholders of SRRP. ${ }^{4}$ All informants in this document are referred to by pseudonyms. Further evidence is derived from the analysis of countless documents, informal conversations and participant observations.

\section{Socio-fugal}

\section{Socio-fugal and Corpo-active}

Many conventions with a socio-fugal and corpo-active agenda fall into the CPTED's category of target-hardening and are meant physically to impede criminal acts. Most related conventions are not unique in any way to Northern Ireland. For example, the Guidelines for minimum security requirements for domestic property are issued by the Master Locksmiths Association (MLA, 2007) of the UK and thus apply to the whole nation. In the same area of validity, but written for a completely different audience, the Hostile vehicle mitigation guide spells out the expectations the National Counter Terrorism Security Office has for certain features of the built environment. Other target-hardening conventions, mostly with an anti-terror focus, include the Blast code TM 5-1300 (US Departments of the Army, the Navy, and the Air Force, 1990) and the DoD minimum anti-terrorism standards for buildings (US Department of Defense, 2007). These and a number of other conventions originated in an American context but are also used, often with some amendments, in other countries. Given that the Irish Republican Army (IRA) was considered a terrorist organisation, certainly by the British state, it is not surprising that certain key locations in Northern Ireland are designed according to similar specifications. The design conventions for police stations, for example, included "metal grills placed to deflect missile attacks ... blast walls and ... bollards designed to prevent car bombs from being driven too close" (Jarman, 1999, p. 4). A selection of these features can be seen in Figure 3. The designers of the SRRP building also followed a number of target hardening conventions. These include the use of toughened, laminated glass, metal grills to protect the windows in the stairwell and roller shutters over all windows, even those on the first floor because the building is in effect still part of a peace wall. The latter requirement proved problematic for the recent addition to the building as the architects had proposed round windows in order to create a friendly, eye-like, appearance of their design. This idea 


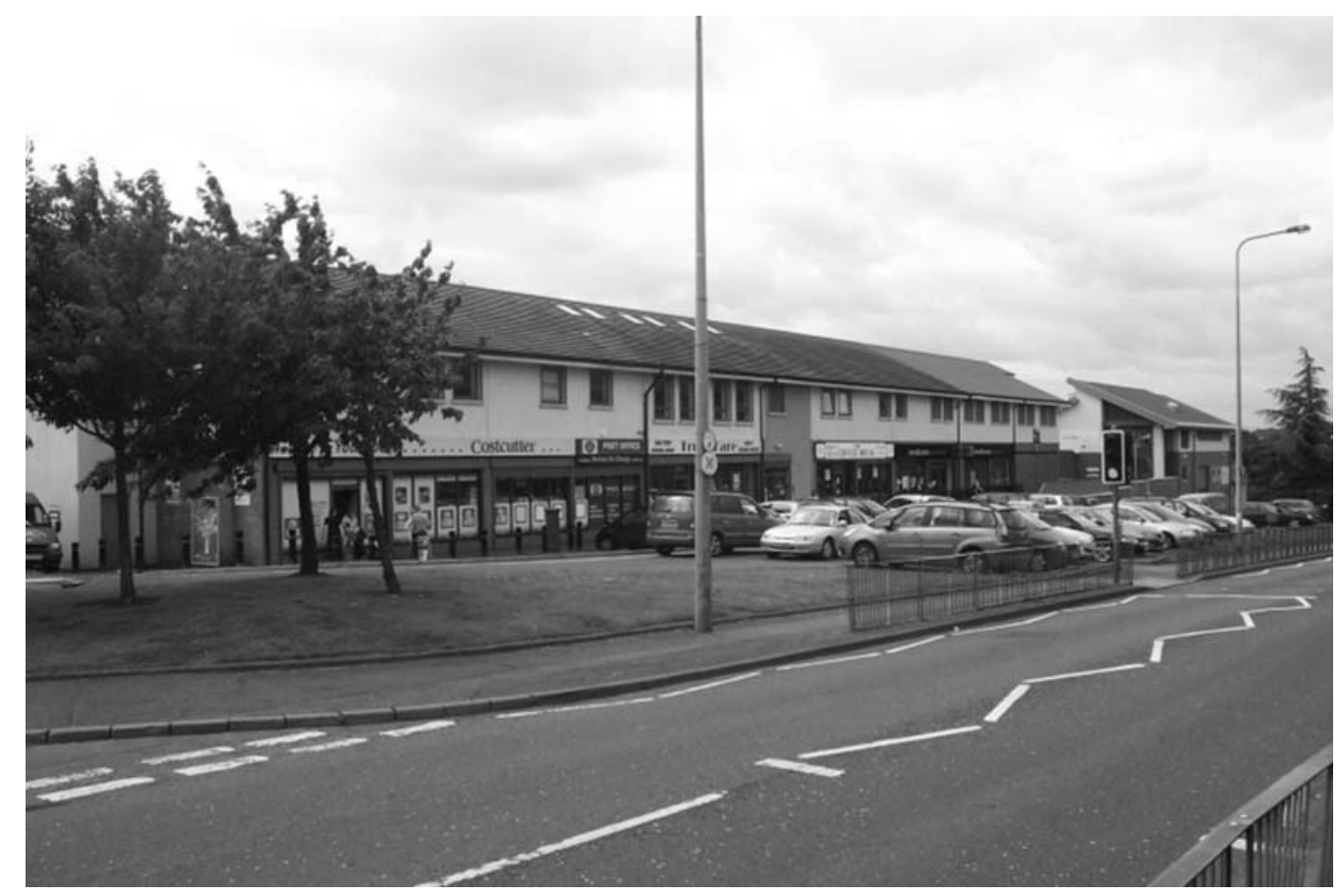

Figure 3. SRRP buildings phase I (left) and phase II (right); the latter included an extension of the first building by two retail units and the construction of a crèche for children from both communities

proved incompatible with Northern Ireland's target-hardening convention due to the unavailability of round roller shutters-that is, until someone discovered, by mere chance, a producer in continental Europe.

Many such design solutions double as means of target-hardening and as means of access control, another key element of CPTED wisdom. Related conventions recommend designing buildings so that persons are guided to reception areas, planting thorny vegetation beneath ground level windows and avoiding features that provide access to roofs or upper levels. The most drastic incarnations of access control conventions in Northern Ireland are the peace walls that scar Belfast's urban fabric (see Figure 4). According to a representative of the Northern Ireland Office, which is in charge of the construction and maintenance of peace walls, their design does not follow any written regulation (Jean McGuire, interview,
25 June 2008). However, the fact that many of them are of a similar height and appearance suggests that some kind of convention is at play. This, it turns out, is the experience of 'how high kids can throw' which sounds like a rule-of-thumb if not like a more established convention. The SRRP building's function as a peace wall explains access control features such as the massive metal bollards along its entire western side (visible in Figure 2), the almost 2.5-metre-high spiky metal fence on the Suffolk-side and the deliberate absence of bushes in the landscaping of SRRP's surrounding. The latter is simply the implementation of the previously mentioned design convention for interfaces in Northern Ireland as it makes it difficult for potential perpetrators to hide themselves or their ammunition (bricks, paint- or petrol-bombs, etc.). Also, the plain, rectangular shape of the SRRP building owes its existence in part 


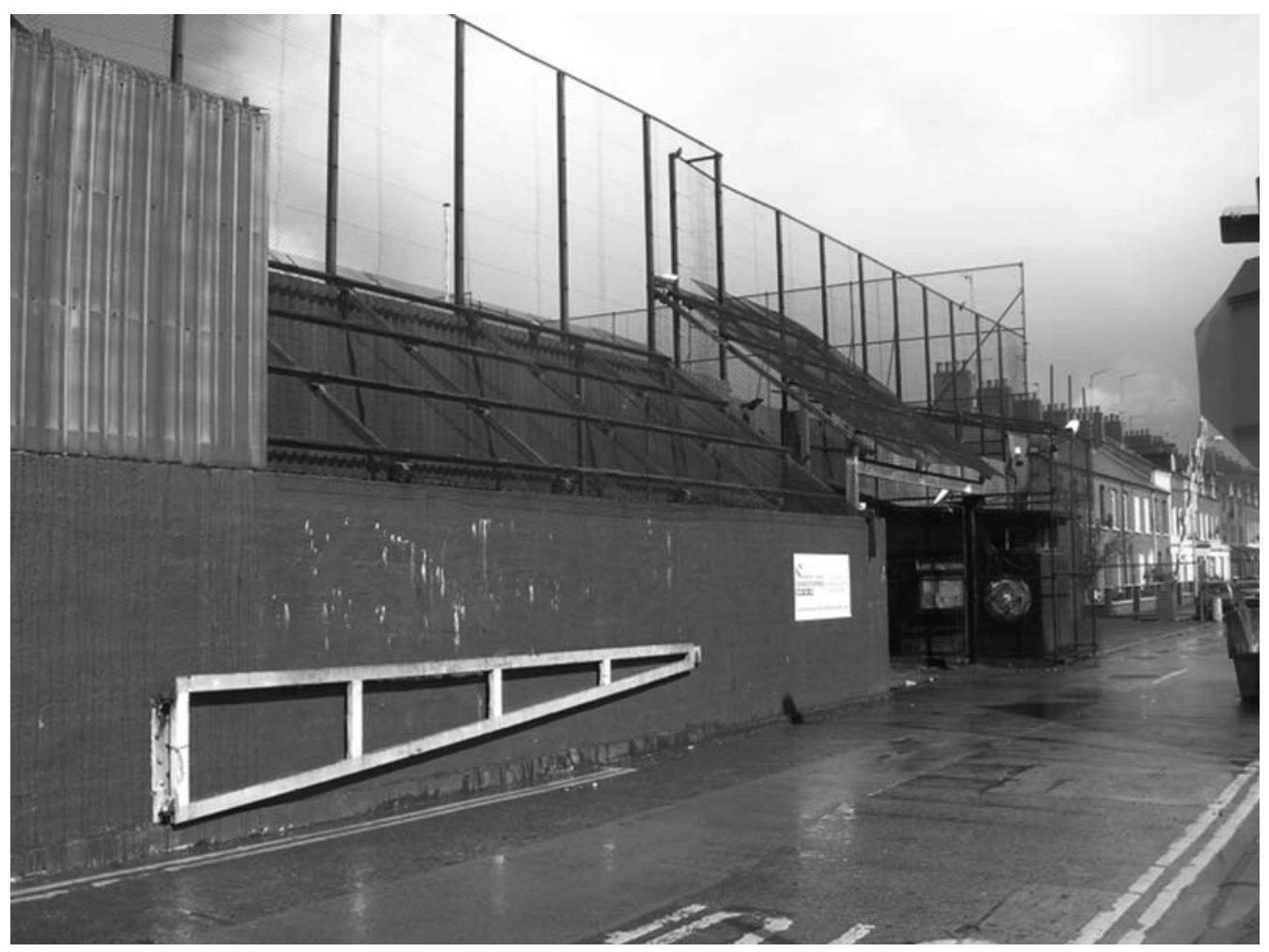

Figure 4. The police station in the Nationalist enclave Short Strand within East Belfast which is predominantly Unionist

to a certain access control logic since alcoves and recesses could be used as hiding-places by attackers. ${ }^{5}$

\section{Socio-fugal and Symbolic}

The socio-fugal conventions within CPTED also include symbolic features which materialise as natural territorial enforcement and natural surveillance. The intended effect of both logics is not based on the physiological but the psychological nature of human beings. The design of places or buildings created according to these conventions does not make undesired actions physically difficult, but acts as a deterrent by signalling the threat of being noticed and identified as a potential perpetrator. The effect of such symbolic features is thus mediated through mental, but not necessarily cognitive, processes. The idea of natural territorial enforcement motivates urban and building designers to delineate visibly public and private spaces in order to signal ownership and thus to create a sense of trespassing on someone else's property. The perceived threat of detection is increased by a deliberate impression of maintenance to suggest alert and active occupiers. This implies that there is a convention to design low-maintenance buildings. A particularly interesting recommendation in this context is to avoid razor-wire fence topping because it signals the absence of the occupier. This example demonstrates how corpo-active and symbolic approaches sometimes run counter to each other and that their application is highly context dependent: a sectarian stone-thrower at a Northern Irish interface, for example, might actually want the intended victims to be present. 
The second CPTED logic that fits into the socio-fugal and symbolic category is the concept of natural surveillance. Generally speaking, it suggests maximising the areas where potential perpetrators can be spotted by (real or potential) observers and thus to raise a psychological barrier for potential perpetrators. This explains the design convention in some areas of Belfast which reverses the traditional sequence of British housing design from street-house-backyard to streetfrontyard-house, which creates extra space where trespassers quickly become conspicuous. Natural surveillance also suggests facing windows towards potential crime areas, to avoid blinding glare, deep shadows and dimly lit areas. This design convention is, of course, not only dictated by natural but also by artificial surveillance considerations (i.e. CCTV). Another natural surveillance convention avoids sight-limiting fencing which can also run counter to the corpo-active idea of target-hardening. This is underlined by the fact that SRRP decided to use mesh fencing with a more symbolic effect to delimit its property in phase II of its development instead of the physically unyielding but sightlimiting metal palisades that were used in phase I, as can be seen in Figure 5 (Michael Norwood, interview, 22 September 2007).

\section{Socio-petal}

As previously mentioned, some attempts are under way in Northern Ireland to create neutral or, even more ambitious, shared spaces for citizens, regardless of their ethnic or religious background. Of crucial relevance for urban designers and architects in this context is the question as to whether the

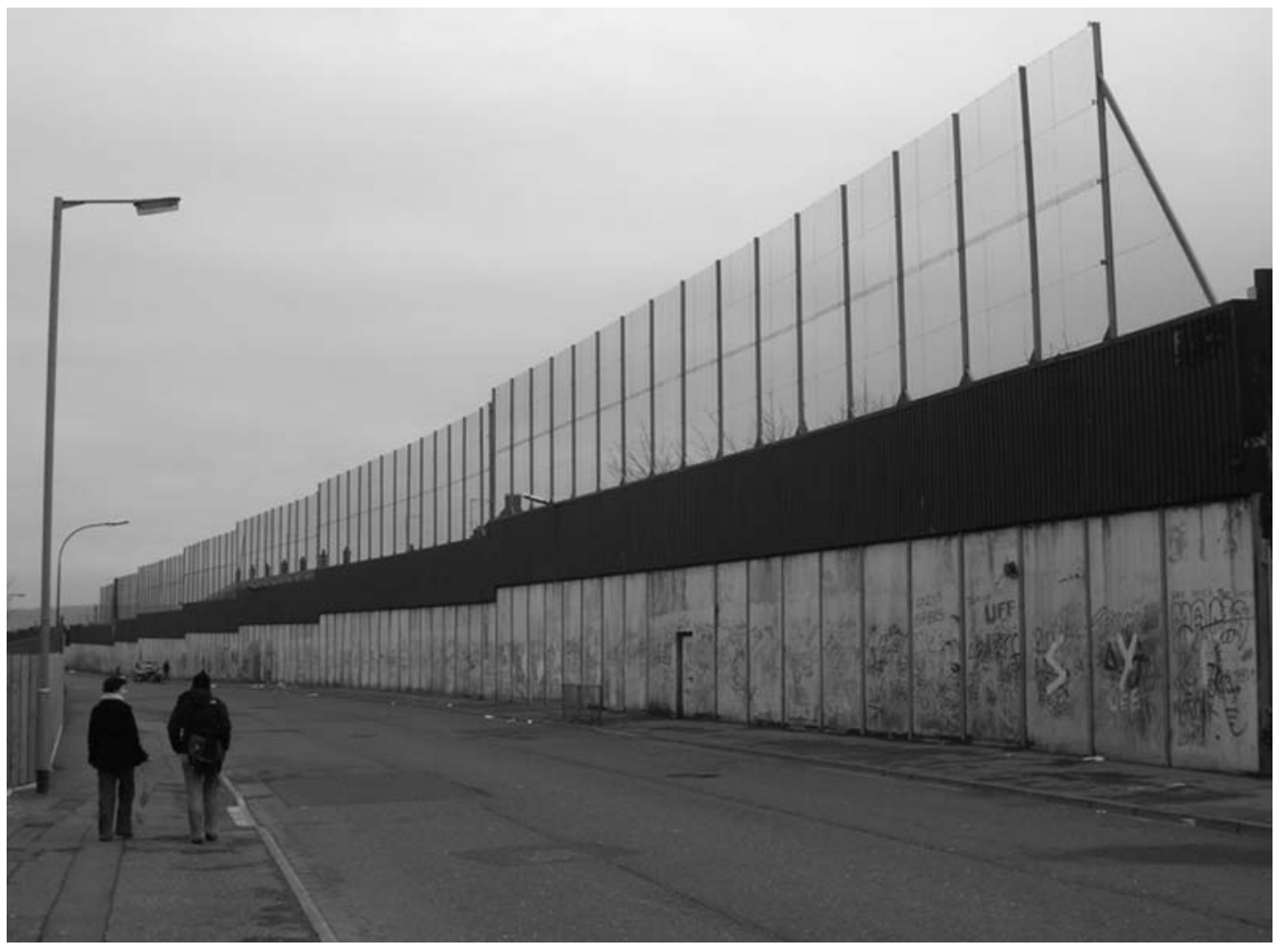

Figure 5. The Cupar Way interface in West Belfast, one of the most blatant peace walls in Northern Ireland 
physical environment can make a contribution to these efforts and, if so, how.

\section{Socio-petal and Corpo-active}

Sometimes, a socio-petal design feature is simply the reverse of its socio-fugal interpretation since what deters some people might attract others. More concretely, what makes the life of a criminal difficult can be the reason why a law-abiding citizen prefers a particular place. This is also the case at SRRP with its many socio-fugal design solutions as mentioned earlier. The existence of socio-petal features that do not actually prevent anyone from doing anything demonstrates, however, that petal is not always simply the opposite of fugal and hence that this distinction has its merits. For example, the new flyovers across the M1 highway (Westlink) that passes just to the west of the Belfast City centre certainly have improved access for residents living on the western side of the city centre as well as for those living on the eastern side of the Royal Victoria Hospital. ${ }^{6}$ They do not, however, prevent those with sectarian or criminal energies from anything.

A similar logic has been applied at SRRP. As can be seen in the floorplan in Figure 6, the ground floor of its phase I building has two separate entries. This contradicts the CPTED convention of using a single, clearly identifiable point of entry. In the case of SRRP, it was considered essential to provide equally convenient and safe access to both communities. Without this dual-access solution, residents of Suffolk would have to enter the building from the opposite side which would be physically inconvenient, requiring a longer walk, and would require entering through the entrance which faces Nationalist territory, which would feel less secure for Suffolk residents for that reason. ${ }^{7}$ Although such a solution emphasises the deplorable truth of how far away certain areas of Belfast

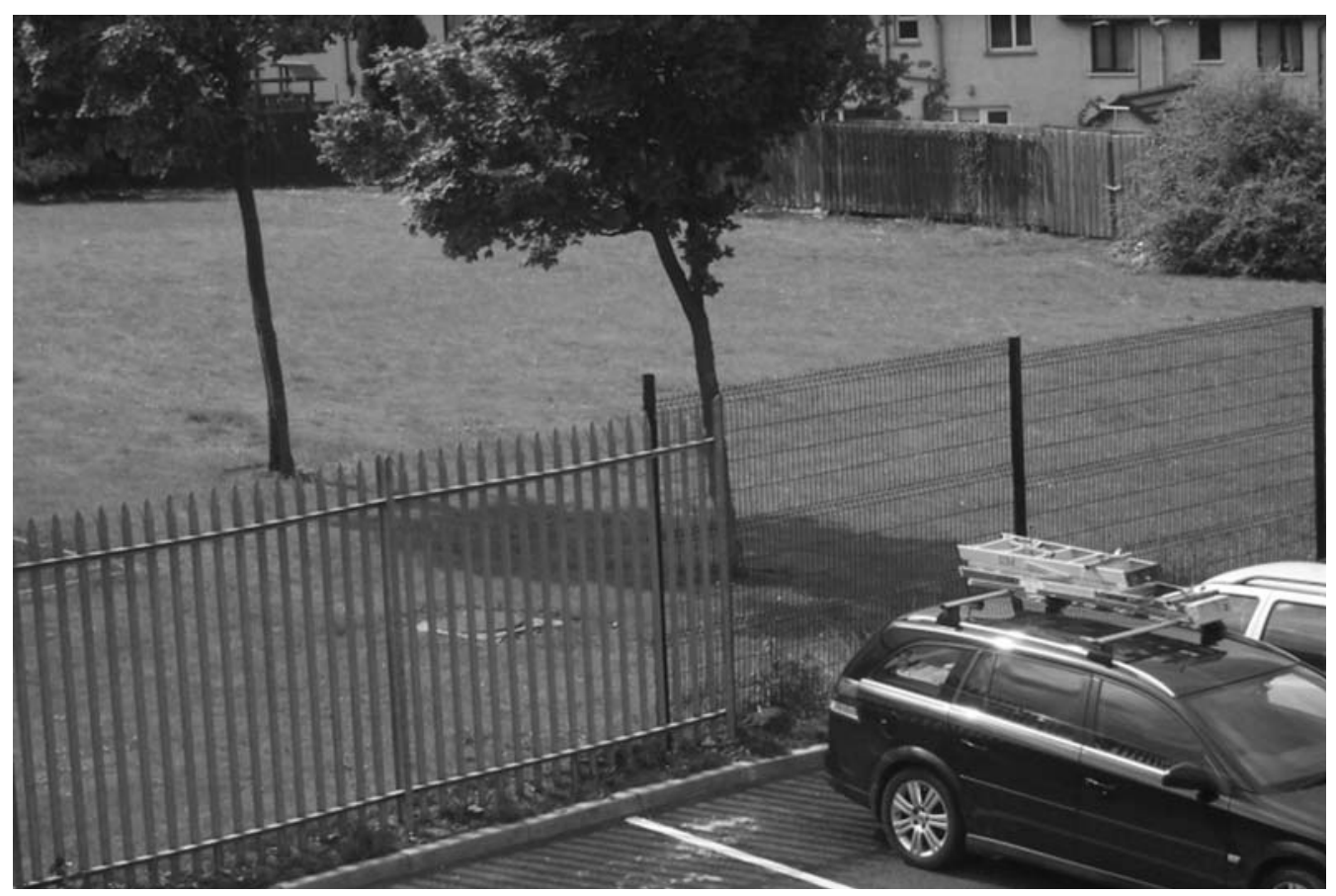

Figure 6. Different types of fence were used in phase I and phase II of SRRP's development because of their particular (dis-)advantages 
are from normality, it is at least a pragmatic acknowledgement of some people's genuine fears and concerns. As an intermediate conclusion, it seems sensible to nominate such a dual entry/exit solution as a candidate for the list of (yet unwritten) socio-petal and corpo-active conventions for the design of shared spaces.

Another item for this list might be the advice to provide the type of facilities that attract the desired clientèle. For example, people who were concerned about the antisocial behaviour with sectarian undertones that was occurring in the waterworks park in North Belfast came up with the idea to stock a pond with fish to attract more lawabiding users, almost as unpaid guardians of the park. Similarly, the Creggan Country Park initiative in London/Derry constructed a small marina at a disused water reservoir, erected a building with a small restaurant and changing rooms and provided canoes and boats to attract youth who want to have harmless and healthy fun-often with children from other backgrounds-instead of the glue-sniffing teenagers who used to hang out in this area (Vivian Murphy, community worker, interview, 24 June 2008). A much grander architectural decision, but with the same rationale behind it, was the construction of the Odyssey entertainment complex in Belfast. It was designed with an ice rink to accommodate an ice hockey team (the Belfast Giants) which was established despite any tradition of ice hockey in the area, and thus there was no baggage of sectarian affiliations. ${ }^{8}$ The ice rink therefore functions as large neutral space.

The SRRP building too was designed to facilitate friendly encounters between the residents of the two adjacent areas. The first floor, for example, contains a kitchen and a sizeable communal seating area (see Figure 7, "Cafe/Seating"). There is also a commercial café on the ground floor. At a more general

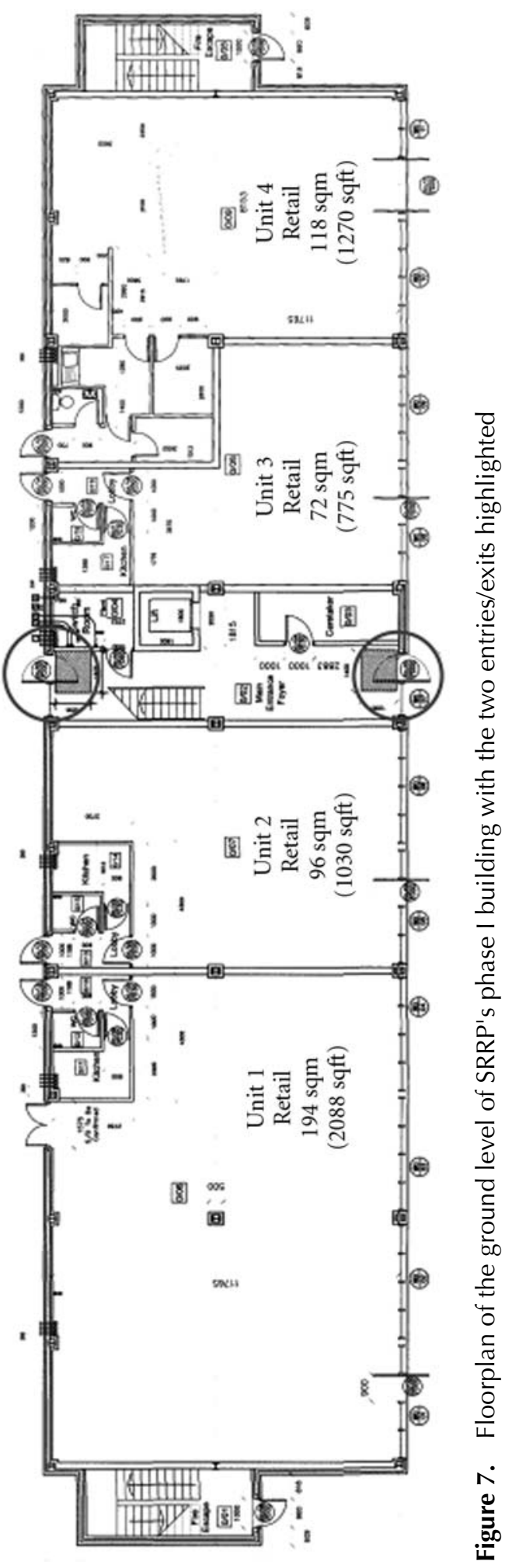


level, it is clear that the architect's brief stipulated the design of store units that cater to people's everyday needs (small supermarket, post office, pharmacist, etc.) rather than, say, a carpet store which would have required much larger premises. In their written "Statement of core values, principles and criteria for use of the Centre", the SRRP company stipulated the kinds of business that they would like to attract to the area and the kinds they would not. The space requirements of and therefore the design solutions for the nursery in phase II of SRRP's building were clearly different, but the idea of attracting an ordinary, wellmeaning clientèle from both communities was exactly the same.

\section{Socio-petal and Symbolic}

Judging by the number of examples that follow, the success of shared spaces seems significantly more dependent on symbolic socio-petal features-that is, material solutions that make a space acceptable to users from different backgrounds without necessarily speaking to the body. The idea of attracting desired users was mentioned earlier, but it can also be applied in this category. For example, highlighting and representing the uncontentious historical value of a place is likely to attract users with an interest in such issues. The Creggan Country Park in London/ Derry runs a project investigating and communicating the importance of this place in the city's history and its role in local folklore, such as in the song "There is a green hill far away" (Evelyn Lynch, community worker, interview, 25 June 2008).

The absence of artefacts with an unpleasant or even intimidating meaning such as sectarian flags, graffiti, emblems, ornaments, etc. is clearly also a key component of successfully shared spaces. Although this prevents some people from displaying their political conviction or even their cultural identity, it does not prevent anyone from using space in any other particular way. On the contrary, spaces free of such territorial markers are welcoming, which facilitates their use by anyone. For this reason, I would suggest classifying this approach as socio-petal. One of five key initiatives of NIHE's Community Cohesion Unit is therefore the removal of sectarian flags and emblems and the search for "more acceptable expressions of cultural identity" (NIHE, 2005, p. 12). Similarly, the SRRP has a zero-tolerance policy for any display of sectarianism on its grounds; in fact, the building is painted with an anti-graffiti coating. However, the semiotic care that went into the design of the SRRP building goes way beyond this. It was clear, for example, that certain colours of the carpets and walls are completely intolerable to one side or the other since green is interpreted as the color of Republicanism and orange is traditionally used to emphasise the Loyalist identity.

Some, but not all, argue that the architectural display of trust is another mandatory design element of neutral spaces. The Waterfront Hall in Belfast, a 2223-seat cultural hub at the edge of the city centre, for example, was built in 1997 with an expansive glass façade, which would have been an anathema before the IRA cease fire (1994) due to the enormous secondary damage that could be caused by glass shards in case of a bomb attack. As Figure 8 shows, the final design decision embraced the façade's symbolic message of transparency and optimism. A plaque in the city centre emphasises that the Waterfront Hall "is an expression of its [Belfast's] confidence as a modern, progressive European city". At the same time, it bluntly violates the corpo-active target-hardening convention of CPTED wisdom. However, this does not justify a universal best-practice lesson. The context-dependence of this issue is demonstrated by SRRP's decision to protect every single window at night with metal roller shutters. This might imply a degree of distrust, but in this particular location, at a still intermittently violent interface-albeit 


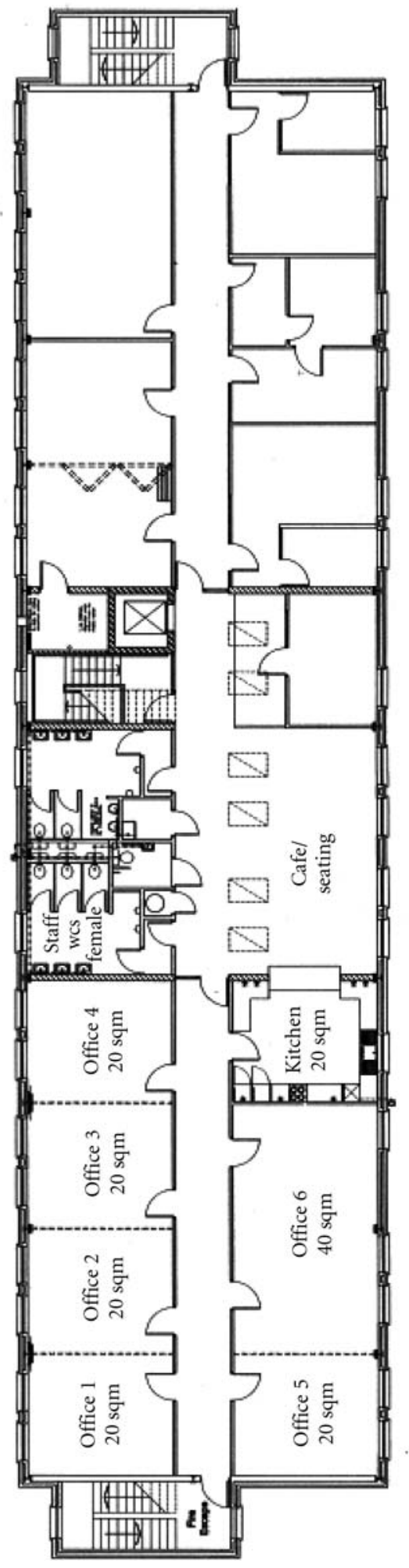

that violence has markedly reduced in recent years-the situation is indeed very different from that in the city centre. This radical contingency makes the development and identification of design conventions for shared spaces very difficult.

A largely undisputed convention is the equal treatment of the different parties involved. Traditionally, in Belfast, this rule has played out in practice when one community has demanded a particular facility (a leisure centre, playground, etc.) whenever the other community got one. Although this formulaic quid pro quo logic is an expression of un-normality, it is pragmatic in the sense that it acknowledges the continued actual sensitivities in many parts of the city. It also prevailed in the design of the community offices on the first floor of SRRP. An early version of the architect's draft did not feature identically sized and shaped offices for the Lenadoon and Suffolk community forums which was immediately pointed out by the 'disadvantaged' group and consequently remedied (Hugh Newman, community worker, interview, 24 September 2007; see floor plan in Figure 7). The rationale of equal treatment also explains why SRRP never refers to either of the two entries mentioned earlier as front or rear access in order to avoid any judgemental treatment of either. This is also the reason why both entries have the very same address, printed in the same font and size on both doors: 124 Stewartstown Road. However, this ideal rhetoric is not reflected in the architectural design and consequently in the real use of the two different entries. It cannot be ignored that the Suffolk side does look and feel like a rear entrance (Figure 9) and it is therefore there where staff take their smoke breaks, away from the gaze of the busy parking space on the Lenadoon side. The critical scholararchitect Caroline Hugh (interview, 28 June 2008) is thus disappointed by this design solution but largely blames the stringent tendering and procurement process which 


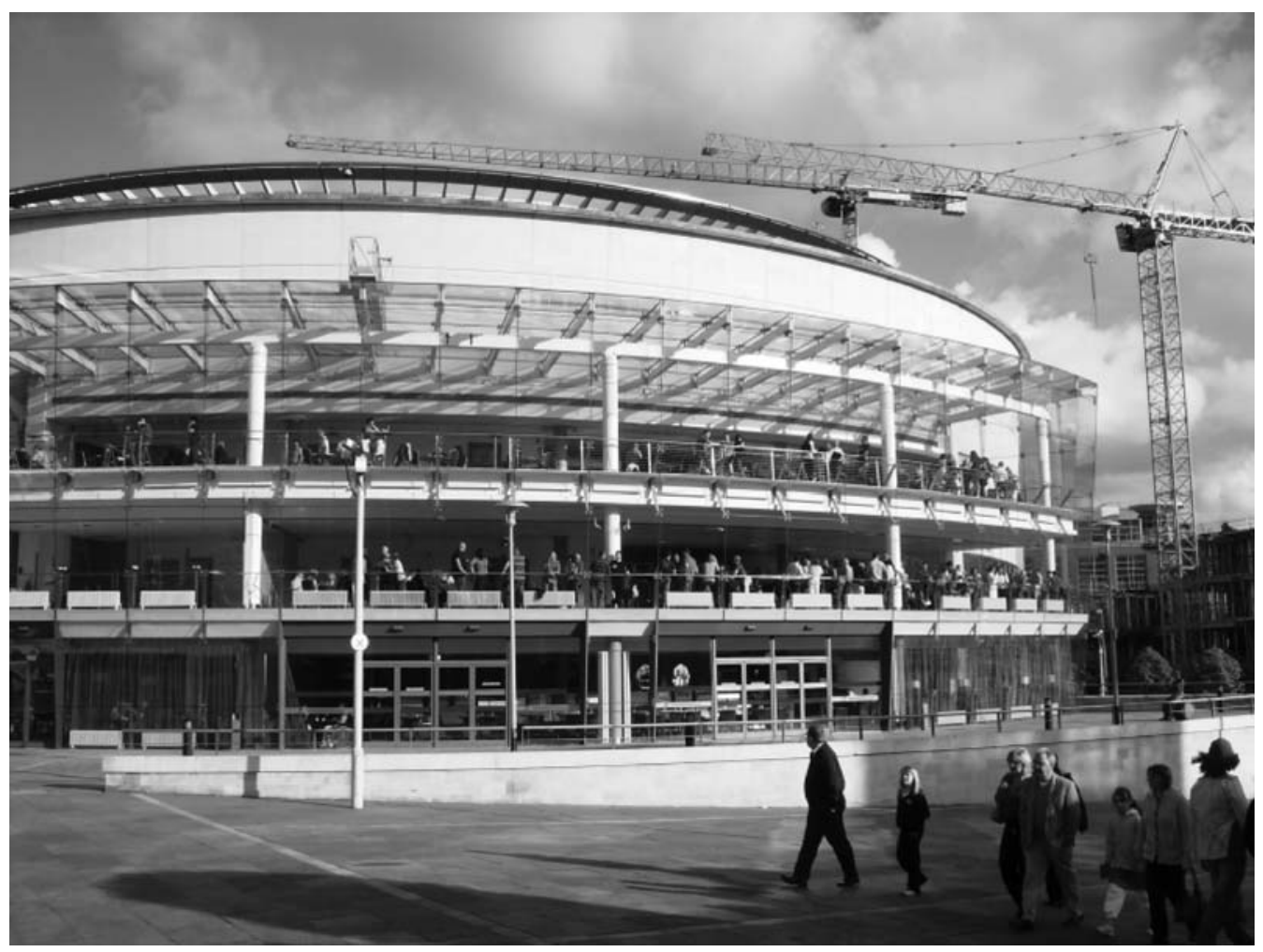

Figure 9. The Waterfront Hall in Belfast, with its expansive glass façade

ensures that creative proposals get stripped down to the bare functional minimum. This point, slightly inverted, implies a call to implement the rule of equal treatment not just functionally but also aesthetically. Michael Norwood, who knows many intricacies of the project, warns about the reverse conclusion of this argument "To have implemented some kind of aesthetic equivalence without the equivalence in signage could have been seen as paying lip service to matters of equality and in extreme may have even been seen as mocking the Suffolk community" (e-mail correspondence, 20 July 2009).

\section{Summary and Conclusions}

Our built environment is more than just a product of designers following their genius intuition in pursuit of pure beauty. As the contributions to this Special Issue demonstrate, a vast range of regulations, rules and conventions are also important factors that co-determine the shape of buildings, places and streets. By implication, such an acknowledgement erodes the autonomous status of the creative hero-architect and might therefore not be wholeheartedly embraced. The overall purpose of this paper is not, however, to provide evidence for the claim that building conventions matter; this position was rather an a priori assumption. I had in mind with the first part of this paper to develop a framework which helps to capture appropriately the different types and aspects of design conventions. Such an attempt would necessarily fail if it only considered legal building regulations and industry standards. Some conventional ways of doing architecture and urban design derive their authority from 


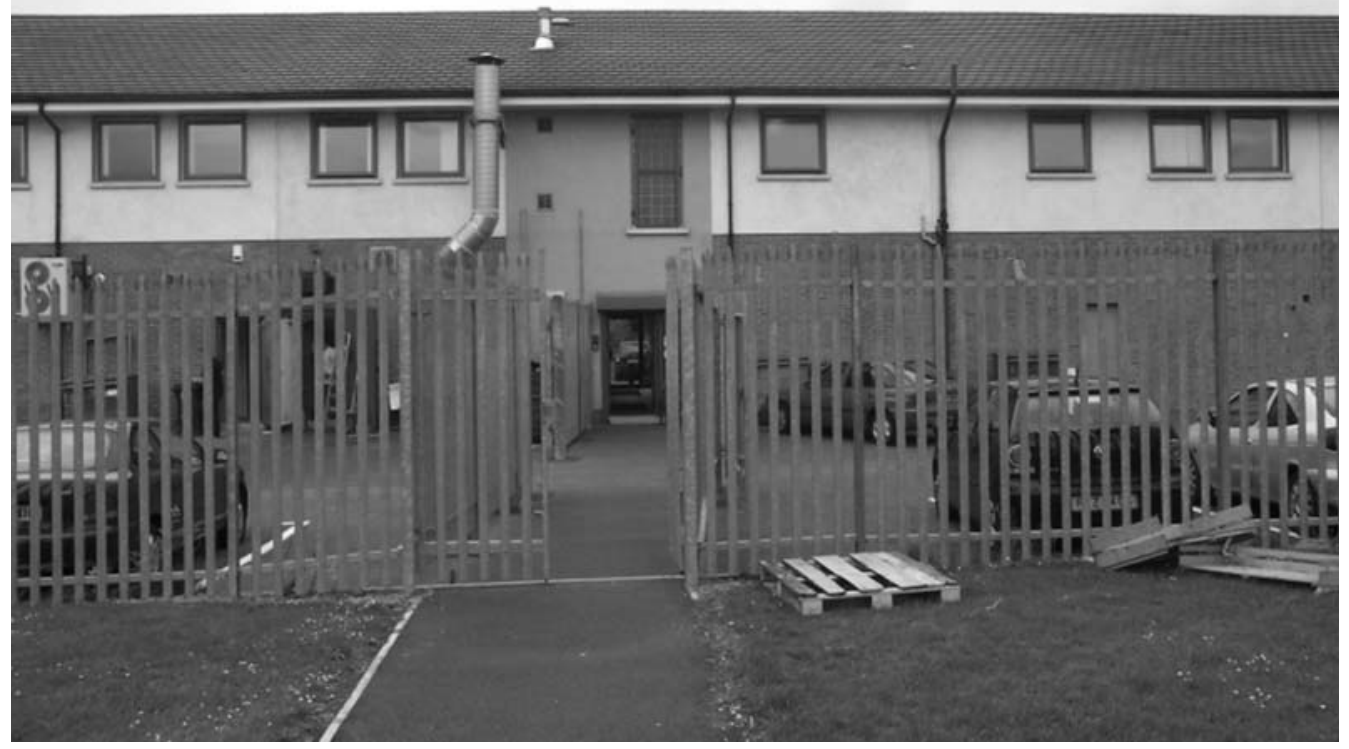

Figure 10. The Suffolk entry to the SRRP building

other sources, are enforced by other means, follow other rationales and exist for other purposes. What is needed, then, is a more nuanced way of thinking about the broad range of de facto building conventions.

Particularly interesting examples of design conventions can be found in a contested city like Belfast. Because of the unique sociopolitical condition, design codes meant to apply nationally are unable to respond appropriately to the idiosyncrasies of the situation in Northern Ireland. Luckily, petrol bomb attacks between different ethnic groups are rare in all but one British city. This explains why no national regulation recommends, let alone stipulates, the absence of trees near interfaces between ethnically homogeneous residential areas. However, interethnic problems are unfortunately still so frequent in Belfast, Lisburn, Londonderry/Derry, Ballymena and too many other towns in Northern Ireland that the exchange of experience between them has led to the emer- gence of a common pool of 'dos' and 'don'ts', a shared basket of know-how or, in other words, a set of sometimes unwritten yet very effective design conventions.

Many of these conventions guide the creation of artefacts with an embedded behavioural agenda. The two-dimensional distinction between socio-fugal/socio-petal effects and corpo-active/symbolic mechanisms was introduced as a heuristic tool to grasp further differences between such socio-active artefacts. The empirical evidence from Belfast is sorted into the resulting four categories. Their description is the main purpose and so covers the main part of this paper. The many examples in Belfast show that attempts to discourage undesired behaviours through the built form are prevalent. The definition of what qualifies as undesired behaviour is hugely contested in Northern Ireland which makes the design of socio-active artefacts a necessarily highly disputed issue. However, the power gradient between those who pursue 
incompatible visions of Northern Ireland's political, urban, concrete and built future is so steep that urban design mostly follows the political and economic mainstream de facto which prefers the absence of violence over its presence. This is not to mask the fact that the absence of violence can simply be the dulling effect of the oppression of dissent. In short, the design practice in Northern Ireland draws a lot of inspiration from the largely sociofugal school of CPTED and is thus guided by a range of articulated, although not legally binding, design recommendations.

Those who aspire to more than a mere stalemate, who are not satisfied with putting a heavy lid on violent mindsets, who aim to facilitate neighbourliness and amicabilityin other words, those who try to incorporate a socio-petal agenda into the built formdo not have the benefit of having widely accepted design guides. So far, we know very little about the kinds of conventions that could govern the creation of spaces where friendly encounters between all social groups could happen. Based on the experience of (admittedly few) attempts to create such places, it seems important to ensure a minimum level of safety which still requires a number of socio-fugal elements, especially at interface locations. However, some conventions designing-out undesired behaviour actually stand in outright contradiction to the idea and practice of sharing spaces. Certain socio-fugal aspects of conventional CPTED wisdom seem potentially to solidify conflict because they make it physically or symbolically difficult to meet the 'others' and thereby perpetuate stereotypisation and distrust. An attempt to design-in amicability must therefore not simply add socio-petal embellishment on top of a socio-fugal foundation. The architects and client of Belfast's Waterfront Hall must have realised this. They demonstrated their trust in the reliability of the IRA cease-fire with an expansive glass façade in an intrepid move to violate proven CPTED conventions. Similarly, SRRP's decision to use mesh fencing instead of metal palisades required a thorough deliberation process and did not follow from the blind implementation of some guideline. Such decisions cannot be prescribed or regulated. They must be a response to the contingency of a particular place at a particular time. At least at this stage, it seems necessary to invent suitable sociopetal design for shared spaces from scratch, one case at a time. ${ }^{9}$ This implies a big role for local knowledge, sensitivity, inventiveness, creativity, dialogue and courage. Yet it would nevertheless help if the basket of inspiration for socio-petal design practice could be filled with more experience.

\section{Notes}

1. The Social/Economic/Environmental Design Network (www.seed-network.org), for example, represents an organisation that attempts to cast a social-environmental agenda into a building certification scheme.

2. I owe this expression to my colleague Andrew Crompton.

3. The most recent phase was part of the project "The urban environment: mirror and mediator of radicalisation?" (ESRC Grant No. RES-18125-0028).

4. Credit is due also to my project assistant, Sara Fregonese, who conducted or joined me on five of these interviews.

5. Another important factor was, of course, financial constraints.

6. The remake of the Westlink also included the construction of a new pedestrian bridge which provides an excellent, because elevated, spot from which certain youths can act out their sectarian mindset by launching stones, paint bombs, etc. into a residential area of the 'others'. The bridge was designed by a foreign engineering consultancy with no knowledge about local sensitivities and design conventions. But this case is a whole different story.

7. The fact that only few people use this corridor does not nullify its important symbolic meaning and its hypothetical role in times of trouble. 
8. Traditionally, cricket, rugby and hockey were affiliated with Protestant traditions, whereas all types of Gaelic sports (hurling, Gaelic football, camogie) are considered Irish/Catholic sports disciplines.

9. This does not mean, however, that experience gained in one place should not be disseminated to other initiatives as long as this knowledge (explicit or tacit) is then adapted to local conditions and new political developments.

\section{References}

Akrich, M. (1992) The de-scription of technical objects, in: W. E. Bijker and J. Law (Eds) Shaping Technology/Building Society: Studies in Sociotechnical Change, pp. 205-224. Cambridge, MA: MIT Press.

Ben-Joseph, E. (2005) The Code of the City: Standards and the Hidden Language of Place Making. Cambridge, MA: MIT Press.

Boal, F. W. (1998) Exclusion and inclusion: segregation and deprivation in Belfast, in: S. Musterd and W. Ostendorf (Eds) Urban Segregation and the Welfare State, pp.99-109. London: Routledge.

Boal, F. W. (1999) From undivided cities to undivided cities: assimilation to ethnic cleansing, Housing Studies, 14(5), pp. 585-600.

Bollens, S. A. (1999) Urban Peace Building in Divided Societies: Belfast and Johannesburg. Boulder, CO: Westview Press.

Bollens, S. A. (2002) City and soul: Sarajevo, Johannesburg, Jerusalem, Nicosia, City: Analysis of Urban Trends, Culture, Theory, Policy, Action, 6, pp. 169-187.

Brand, R. (2008) Co-evolution of technical and social change in action: Hasselt's approach to urban mobility, Built Environment, 34(2), pp. 182-199.

Brand, R. (2009) Urban artefacts and social practices in a contested city, Journal of Urban Technology, 16(2), pp. 35-60.

Calame, J. and Charlesworth, E. (2008) Divided Cities: Belfast, Beirut, Jerusalem, Mostar and Nicosia. Philadelphia, PA: University of Pennsylvania Press.

Callon, M. (1986) Some elements of a sociology of translation: domestication of the scallops and the fishermen of St-Brieue Bay, in: J. Law (Ed.) Power, Action and Belief: A New Sociology of Knowledge, pp. 196-233. London: Routledge and Kegan Paul.

Charlesworth, E. (2006) Architects without Frontiers: War, Reconstruction and Design Responsibility. Oxford: Architectural Press.

Community Relations Council (2008) Towards sustainable security: interface barriers and the legacy of segregation in Belfast (http://www.communityrelations.org.uk/filestore/documents/iwgpublication.pdf; accessed 18 July 2008).

Corsini, R. J. (1999) The Dictionary of Psychology. Philadelphia, PA: Brunner/Mazel.

Cowan, C. (1982) Belfast's hidden planners, Town and Country Planning, 51(6), pp. 163-167.

Dawson, G. (1984) Defensive planning in Belfast, Irish Geography, 17(1), pp. 22-41.

Gaffikin, F. and Morrissey, M. (2006) Planning for peace in contested space: inclusion through engagement and sanction, International Journal of Urban and Regional Research, 30, pp. 873-893.

Gibson, J. (1977) The theory of affordances, in: R. Shaw and J. Bransford (Eds) Perceiving, Acting, and Knowing, pp. 67-82. Hillsdale, NJ: Lawrence Erlbaum Associates.

Hall, M. (Ed.) (2007) Building bridges at the grassroots: the experience of Suffolk-Lenadoon Interface Group. Island Pamphlets No. 81, Island Publications, Newtonabbey, Co. Antrim (http:// cain.ulst.ac.uk/islandpublications/hall07-ip81. pdf; accessed 15 July 2008).

Hillyard, P. (1983) Law and order, in: J. Derby (Ed.) Northern Ireland: The Background to the Conflict, pp. 17-33. Belfast: Appletree Press.

Imrie, R. and Street, E. (2009) Regulating design: the practices of architecture, governance and control, Urban Studies, 46(12), pp. 2507-2518.

Jarman, N. (1999) Troubling remnants: dealing with the remains of conflict in Northern Ireland. Proceedings of the World Archaeological Congress 4, University of Cape Town, January (http:// www.wac.uct.ac.za/wac4/symposia/papers/ S040jrm1.pdf; accessed 14 April 2006).

Latour, B. (1992) Where are the missing masses? The sociology of a few mundane artefacts, in: W. E. Bijker and J. Law (Eds) Shaping Technology/ Building Society: Studies in Sociotechnical Change, pp. 225-264. Cambridge, MA: MIT Press.

Latour, B. (1999) Pandora's Hope: Essays on the Reality of Science Studies. Cambridge, MA: Harvard University Press. 
Latour, B. (2004) Which politics for which artefacts?, Domus, June (http://www.bruno-latour.fr/ presse/presse_art/GB-06\%20DOMUS\%200604.html; accessed 16 July 2008).

Loizidou, M., Pellapaisiotis, H. and Stratis, S. (2007) Cyprus: the 'Call No. 192' project, in: B. Vlay, P. Rajakovics and M. Studen (Eds) European Urbanity: Europan 7 and 8-Austria and Slovenia, pp. 52-61. Vienna: Springer.

McEldowney, J. M., Sterrett, K. and Gaffikin, F. (2001) Architectural ambivalence: the built environment and cultural identity in Belfast, in: W. Neill and H.-U. Schwedler (Eds) Urban Planning and Cultural Inclusion: Lessons from Belfast and Berlin, pp. 100-111. Basingstoke: Palgrave.

MLA (Master Locksmiths Association) (2007) Guidelines for minimum security requirements for domestic property, 4th edn (http:// www.locksmiths.co.uk/pdf/homeSecurity/ Guidelinesforsecurity.pdf; accessed 22 May 2008).

Morrissey, M. and Gaffikin, F. (2006) Planning for peace in contested space, International Journal of Urban and Regional Research, 30(4), pp. 873-893.

Murtagh, B. (2002) The Politics of Territory: Policy and Segregation in Northern Ireland. Basingstoke: Palgrave.

Newman, O. (1972a) Defensible Space: Crime Prevention through Urban Design. New York: Macmillan.

Newman, O. (1972b) Defensible Space: People and Design in the Violent City. London: Architectural Press.

NIHE (Northern Ireland Housing Executive) (2005) Building good relations: community cohesion. Brochure HR/68/08/04, NIHE, Belfast.

OFMDFM (Office of the First Minister and Deputy First Minister) (2005) A shared future: policy and strategic framework for good relations in
Northern Ireland (http://www.asharedfutureni. gov.uk/gprs.pdf; accessed 7 May 2008).

Osmond, H. (1957) Function as the basis of psychiatric ward design, Mental Hospitals, Architectural Supplement, 8, pp. 23-29.

Purbrick, L., Aulich, J. and Dawson, G. (2007) Contested Spaces: Sites, Representations and Histories of Conflict. New York: Palgrave.

Shaftoe, H. (2008) Convivial Urban Spaces: Creating Effective Public Places. London: Earthscan.

Shirlow, P. and Murtagh, B. (2006) Belfast: Segregation, Violence and the City. London: Pluto Press and University of Michigan Press.

Shuttleworth, I. and Lloyd, C. (2006) Are Northern Ireland's two communities dividing? Evidence from the census of population 1971-2001, Shared Space, 2, pp. 5-14

Sommer, R. (1967) Sociofugal space, The American Journal of Sociology, 72, pp. 654-660.

US Department of Defense (2007) DoD minimum anti-terrorism standards for buildings (http:// www.oca.gsa.gov/odoc/gsaredesign/ALL/ pdfs/ufc_4-010-01_22Jan2007.pdf; accessed 16 July 2008).

US Departments of the Army, the Navy, and the Air Force (1990) Structures to resist the effects of accidental explosions. Army TM 5-1300, Navy NAVFAC P-397, Air Force AFR 88-22 (http://www.ddesb.pentagon.mil/TM\%2051300,\%20November\%201990.pdf; accessed 16 July 2008).

Verbeek, P.-P. (2005) What Things Do: Philosophical Reflections on Technology, Agency, and Design, transl. by R. P. Crease. University Park, PA: Pennsylvania State University Press.

Weizman, E. (2007) Against networking, in: B. Vlay, P. Rajakovics and M. Studen (Eds) European Urbanity: Europan 7 and 8-Austria and Slovenia, pp. 141-143. Vienna: Springer.

Winner, L. (1977) Autonomous Technology: Technics-out-of-control as a Theme in Political Thought. Cambridge, MA: MIT Press. 